\title{
CONFLICTING RIGHTS, DUTIES AND LIABILITIES OF INTERESTED PARTIES UPON ASSERTION OF ADVERSE CLAIMS TO BANK DEPOSITS
}

$\Lambda$ DEMAND for the balance of a bank deposit by someone other than the nominal depositor is an infrequent occurrence. Because such demands are not often made, no well-defined pattern of consequences follows them, and the bank is deprived of any obvious standards by which to regulate its behavior in response to the demands. Similarly, if a court is called upon to judge the sufficiency of the bank's behavior, there are no readily discernible criteria by which to measure the bank's performance.

It is the purpose of this examination of adverse claim litigation to illuminate the considerations facing banks and courts in adverse claim situations. The phrase "adverse claim to a bank deposit" is taken to mean and is used to refer to a claim made by or on behalf of the claimant, notifying a depositary bank that certain monies which it has credited to the account of a depositor belong to the claimant; and instructing the bank not to pay over the deposit or some part of it to the depositor or to anyone claiming under him, or demanding that the deposit or some part of it be paid to the claimant. The phrase is not used to refer to the knowledge of the depositary bank that a person other than the depositor is entitled to the deposit or some part of it. Thus, where the bank is fully cognizant of the equitable rights of a party other than the nominal depositor of the money, but no actual notice has been given nor demand made upon the bank to prevent the transfer of the money in the normal course of business, the situation will not be considered an adverse claim case. ${ }^{1}$

\section{General Adverse Claim Situations}

Adverse claim litigation, while not extensive, falls into several distinct categories. These categories, each of which centers around a type situation with numerous deviations, differ materially in the operative facts, and conse-

1. Common fact situations of this type are: claim of principal or cestui cue trust against bank for aiding in misappropriation of funds by agent or trustec, after notice of nature of act [see Empire Trust Co. v. Cahan, 274 U. S. 473 (1927); Note L. R. A. 1915B 715]; claim of alleged rightful owner of deposited funds to portion of funds applied by bank to antecedent indebtedness of nominal depositor, where bank was on notice of claimant's ownership [See Notes (1921) 13 A. L. R. 324, (1924) 31 A. L. R. 756, (1927) 50 A. L. R. 632] ; claim of alleged rightful owner against bank for permitting funds to be withdrawn or transferred to other persons, after notice of plaintiff's equitable ownership [Commercial Nat. Bank of Independence, Kan. v. Stockyards Loan Co., 16 F. (2d) 911 (C. C. A. 8th, 1926), cert. denicd, 275 U. S. 547 (1927); Burtnett v. First Nat. Bank of Corunna, 38 Mich. 630 (1878)]. 
quently the practical reactions of banks have been diverse. Nevertheless, courts have tended to apply the same legal principles in all situations.?

1. "Simple Adverse Claims" - Money II ronyfully Deposited. The elemental adverse claim arises when a third party claims money deposited in the name of another, alleging that it was either stolen from him or deposited without his consent. ${ }^{3}$ This category encompasses cases where the muney was misappropriated prior to the deposit or where the deposit itself may be termed a misappropriation." The distinguishing element in this group of cases is the fact that the money was never deposited with the consent of the rightiul owner. The simplest case is that in which a thief deposits stolen money in his name, and the rightful owner then demands payment from the bank.5 Another simple adverse claim arises when money on deposit is alleged to have been obtained through the fraudulent sale of property helonging to the adverse claimant. ${ }^{6}$ Similar adverse claims may be advanced against deposits in the name of third persons who acquired the funds directly from misappropriators, $^{7}$ or against deposits secured by alleged fraudulent acts perpetrated against adverse claimants. ${ }^{8}$ In addition to these adverse claims based upon the fact that funds were wrongfully obtained, there is a second class of simple adverse claims - those in which the money was properly in the hands of the customer, but the deposit in the bank was wrongful. Characteristically this type of case occurs when public muney is placed in depusitaries contrary to state law, and adverse claimants, representatives of the government, assert rights to the funds against the nominal depositor or those claiming under him. This situation occurs must frequently when the depositary is insolvent or has made an assignment for the benefit of creditors and the adverse claimant seeks to obtain a preference.

2. "Latent Adverse Claims" - Moncy Properly Deposited. These adverse claims resemble simple adverse claims except for the fact that the funds

2. An analysis of the material facts of each case is nceessary, because conficting dogmas may cause the case to turn on the relationship between customer and adverse claimant and the means by which the customer obtained the disputed money.

3. Barnard v. First Nat. Bank of Newpoint, Ind., 61 Ind. App. 634, 111 X. E. 451 (1916) ; MfcGuiness v. Bank of New South Wales, 1 N. S. IT. L. R. 97 (1880).

4. Marquette Fire \& Water Commissioners v. Wilkinson, 110 Mich. 655, 78 ג. W. 893 (1899) ; Brogan v. Kreipe, 116 Kan. 505, 227 Pac. 261 (1924).

5. First State Bank \& Trust Co. v. IFirst Xat. Bank of Canton, 314 III. $26 \%, 145$ N. E. 382 (1924); Miller v. Eank of Washington. 170 Х. C. 152, 96 S. E. 977 (1918); Calland v. Loyd, 6 M. \& W. 26, 151 Eng. Rep. 307 (Ex. 1840).

6. First Nat. Bank of Wellsborough v. Bache, $71 \mathrm{~Pa} .213$ (1872); Bell v. Hunt, 3 Barb. Ch. 391 (N. Y. 1848).

7. National City Bank v. Continental Nat. Bank \& Trust Co. 83 I. (2d) 134 (C. C. A. 10th, 1936); Pearce v. Dill, 149 Ind. 136, 4S N. E. TS (1897); Banque Eelge v. Hambrouck, [1921] $1 \mathrm{~K}$. B. 321.

S. Barnard v. First Nat. Bank of Newpuint, i1 Ind. App. 634, 111 X. E. 451 (1916) ; Peter Adams Co. v. National Shoe \& Leather Bank, t4 Hun 629, 9 X. Y. Supp. 75 (Sup. Ct. 1887). 
have been properly deposited in the bank. Although the money may be deposited in the name of the customer, the depositor usually occupies the position of agent or trustee, and the claim which is being asserted is that of the principal or cestui que trust. The claim may be based on the fact that the trust is revocable by the settlor who is also the cestui; or a cestui without the power to terminate the trust may sue for an accounting or to substitute another trustee. In any event, the bank receives information from, notice from, demand by or legal process instituted by a non-depositor who claims that the funds on deposit are his, and demands that the bank safeguard the funds. ${ }^{9}$ It is important to distinguish cases in this group from cases in which the cestui or principal has done no more than notify the bank that the fiduciary customer is misappropriating funds of his trust. In such circumstances, the bank will obtain good debits against the customer for all checks which are not misappropriations; whereas in the adverse claim cases, the bank is given notice or is served with legal process in an action by the cestui or principal to terminate the bank's power to honor the demands of the customer, and to require the bank to pay over the balance. Under these circumstances, the bank cannot set up against the adverse claimant any subsequent payment to the customer, regardless of the propriety of the latter's actions.

A typical latent adverse claim arises when a principal notifies the bank that the agency of a clepositor has been revoked and that no further checks drawn by the agent should be honored. ${ }^{10}$ Fact situations involving deviations in the behavior of the agent which cause the rightful owner to notify the bank of the exact or the new scope of the agent's power fall well within this group. Exemplary are cases of the narrowing of the agency scope to permit the agent to act only with the principal's consent; ${ }^{11}$ the deposit by the agent of funds for the benefit of the former principal following revocation of his authority, ${ }^{12}$ and other situations in which the money is properly deposited but those claiming through or under the principal seek to protect the deposit from future action by the depositor. ${ }^{13}$

9. German Exchange Bank v. Board of Comm'rs of Excise, 6 Abb. N. C. 394, 57 How. Pr. 187 (N. Y. 1879); Patterson v. Marine Nat. Bank, 130 Pa. 419, 18 Atl. 632 (1889) (two cases).

10. France Milling Co. v. First Nat. Bank of Cobleskill, 138 App. Div. 645, 122 N. Y. Supp. 736 (3d Dep't 1910); Société Coloniale Anversoisc v. London \& Brazilian Bank, [1911] 2 K. B. 1024; Tassell v. Cooper, 9 C. B. 509, 137 Eng. Rep. 990 (C. P. 1850).

11. Arnold v. Scdalia Nat. Bank, 100 Mo. App. 474, 74 S. W. 1038 (1903).

12. Parks v. Knickerbocker Trust Co., 137 App. Div. 719, 122 N. Y. Supp، 521 (1st Dep't 1910).

13. See Re Interborough Consol. Corp., 267 Fed. 914 (S. D. N. Y. 1920) in which holders of preferred stocks in an insolvent corporation obtained a right superior to the trustee in bankruptcy against certain funds which the company had allocated for payment of dividends. Here the money was properly held, and the equitable owners sought to prevent its further dissipation by those claiming under the depositor. 
3. "Protcctive Advcrse Claims" - Claims Arising afler Legal Aclion ar by Operation of Laii. This third group of adverse claims is identical to latent claims in that the money is properly deposited in the hank, and remains credited to the nominal depositor until the equitable owner is forced by external circumstances to protect himself. The distinction between the two groups lies in the motivating force behind the assertion by the adverse claimant of his rights to the deposit. In protective adverse claims, the third party claiming part or all of the fund left on deposit with the depositary sues to protect his money from actions of other parties either claiming through nominal depositors in a derivative action or asserting independent rights to the deposit. Questions of the misappropriation of the funds by the agent or trustee and of the scope of the authority of the numinal depositor are not therefore involved. As a practical matter, the adverse claimant does not proceed voluntarily but is forced to defend his rights or risk loss of his deposit.

The most common situation falling within this category is the action of garnishment or attachment brought by a creditor of the nominal depositor to apply the credit balance to the payment of the debt. ${ }^{14}$ Upon such action, the equitable owner is forced to dispute the apparent ownership of the nominal depositor, and thus an adverse claim is asserted. The converse case in which the creditor of the equitable owner seeks garnishment or attachment process to run against money rightfully deposited in the name of the customer, also falls within this.group. ${ }^{15}$ Here, the adverse clain is arlvanced derivatively from the right of the equitalle owner, although the latter does not himself seek to prevent further apjoropriation by the agent or trustee. Included in this category, too, are cases in which the adverse claimant must act to prevent the dissipation of the deposited funds by operation of law. Thus, upon the death of a trustee, the beneficiaries of the trust may be forced to take action to prevent the executor of the trustee's estate from treating the funds as the personal property of the decensed trustec. ${ }^{16}$ Or upon a general assignment for the benefit of creditors by the nominal depositor, the prudent equitable owner is compelled to dispute the assignor's title to the property, if he is to protect himself. ${ }^{17}$. In adverse claim also

14. Cunningham v. Bank of Nampa, 13 Idaho 167, sS Pac. 975, 10 L. R. A. (:is.) 706 (1907); Levin v. Lerner, 290 Mass. 294, 195 x. E. 387 (1935); Bank of Northern Liberties v. Jones, $42 \mathrm{~Pa} .536$ (1862), aff'd sub nmm. Jones v. Banls of Northern Liberties, $44 \mathrm{~Pa} .253$ (1863).

15. Simmons v. Almy \& Trustee, 100 Mass. 239 (1868); Catanzaro \& Sons v. Hellman Commercial Trust \& Savings Bank, 281 Pa. 468, 120 Atl. 812 (1924); Rodwwell v. Silvara, $45 \mathrm{~Pa}$. Super. 505 (1911).

16. First Nat. Bank of Portland v. Reynolds, 127 Me. 340,143 At. 246, 60 A. L. R. 712 (1928) ; Bruff v. Rochester Trust \& Safe Deposit Co., 118 Mlisc. 394, 193 N. Y. Supp. 321 (Sup. Ct. 1922). See Runkle's Adm'r v. Runkle's Adm'r, 112 Va. $7 \& S_{1} 72$ S. E. 695 (1911).

17. Webb v. Newhall, 274 Pa. 135, 117 Atl. 793, 20 A. L. R. 1, 3 (1922). 
arises by operation of law when the bank sets up the right of the equitalle owner to prevent withdrawal by the nominal depositor. ${ }^{18}$ Thus, if the equitable owner obtains a judicial declaration that the money on deposit belongs to him, and therefore cannot be applied to an overduc note owed by the nominal depositor to the depositary, an adverse clain to the money may be set up by the bank to prevent withdrawal by the depositor. ${ }^{10}$

4. "Reversed Adverse Claims" - Deposit of Moncy by the Customer in the Name of a Third Party. The fourth category - reversed adverse claims 20 - is distinguishable from the first three groups in that the customer accepting the contract of deposit from the bank does not place the money to his account, but places it under a fictitious name, or under the name of a third party. Thus, the bank generally has no dealings at all with the nominal depositor, and the adverse claim is asserted by the same party that contracts for the disputed deposit. Moreover, an additional legal question is usually present - whether the deposit of the money constitutes a good gift," whether there has been sufficient acceptance on the part of the nominil depositor to render him the equitable owner of the property. The typical case in this group occurs when the owner deposits funds in a bank in the name of his wife or child in an effort to escape garnishment or attachment by his creditors. ${ }^{22}$ Occasionally a deposit in the name of a third person is utilized to complete a present or future gift to the nominal depositor, and the adverse claimant, advancing the contention that no valid transfer has been effected, may be either the original owner desiring to regain possession of his money, ${ }^{23}$ or a creditor or assignee asserting rights under the original owner. $^{24}$

Although the fact situations in all of these cases appear simple, they are normally presented in more complex form. Litigation will at all times involve three, often four or more parties. Since the subject has not been comprehensively treated by the courts many points of litigation are still unsettled.

18. See Nolting v. Nat. Bank of Va., 99 Va. 54, 37 S. E. 804 (1901).

19. Hanna v. Drovers' Nat. Bank, 194 Ill. 252, 62 N. E. 556 (1901).

20. In this category, of necessity, are included certain fact situations which may also be considered as examples of protective adverse claims.

21. The focal point of adverse claims lies in the action of the bank subsectuent to information or notice of the adverse claim and the disposition of the funds under dispute. The validity or invalidity of the claimant's demands against the bank is imminterial, except in regard to the possible liability of the bank for action taken after the receipt of notice. The problem of what constitutes a gift or an equitable right to the money on deposit in another's name, is not pertinent to the discussion.

22. Valley Bank \& Trust Co. v. Parthum, 47 Ariz. 496, 56 P. (2d) 1342 (1936), 48 Ariz. 87, 59 P. (2d) 335 (1936) ; Broderick v. Waltham Savings Bank, 109 Mass. 149 (1872) ; Wallis v. First Nat. Bank of Bluejacket, 117 Okla. 142, 245 Pac. 626 (1926).

23. People of State of N. Y. v. State Bank of Fort Edward, 36 Hun 607 (N. Y. $1885)$; Viets v. Union Nat. Bank, 101 N. Y. 563, 5 N. E. 457 (1886).

24. Albro Co. v. Union Dime Sav. Inst., 15 App. Div. 351, 44 N. Y. Supp. 150 (1st Dep't 1897). 
The problem of first importance in all types of adverse claim cases is what action the bank should take immediately after receipt of the notice of adverse claim from the alleged equitable owner in order to prevent further litigation and to minimize its risk of loss. The concomitant prollem is how best to protect other parties concerned from unwarranted loss and unnecessary litigation. It is to the solution of these questions that any consirleration if adverse claims must. be directed.

\section{General Principles of Applicarle Bankini Laww}

Under ordinary circumstances, the presumption is that moncy on lepusit in a bank belongs to the person in whose name the deposit was malk; the bank is compelled to recognize the right of the nominal depasitor to the funds. This obligation stems directly from the contract hetween the hank and the depositor. ${ }^{25}$ Where the deposit is made in the name of the depositur as "attorney", "agent", or "executor", without any disclosure of the hentficiaries, the designation is treated as a mere descriplio personae.2n It does not affect the character of the account, and the lank is olligated th the nominal depositor by virtue of its contract with him. The bank is not put on notice that the funds might belong to someone ather than the nominal depositor. ${ }^{27}$

The contract of deposit creates the obligation of the bank to pay the sum to the depositor upon a demand for withdrawal. In the absence of notice of an adverse claim to the money, or specific contractual terms to the contrary, the bank may then assume that the nominal depositor, whether or not described as an agent, attorney, or trustee, has the right to withiraw the money under the terms of the deposit agreement. ${ }^{28}$ Similarly, the hank is under the duty to honor the checks of the depositor upon presentment to the extent of the deposit; failure to honor checks properly presented subjects the bank to the possibility of an action by the depositor for slander of crelit damages. ${ }^{29}$

The bank owes its customers duties other than those which usually aceompany the borrowing and lending of money. One of the primary obligations

25. Tiffany, Banks \& Baxking (1912) 43.

26. Cunningham v. Bank of Nampa, 13 Idaho 167, \&8 Pac. 975 (1907); Gladden v. Columbiana Sav. Bank, 235 Ala. 541, 180 So. 548 (1938).

27. Even if the account specifically stands in the name of the customer as fiduciary for a named beneficiary, the bank may not ignore its relations with the customer [Wallser v. Manhattan Bank, 25 Fed. 247 (C. C. W. D. Tenn. 1885); American Trust \& Banling Co. v. Boone, 102 Ga. 202, 29 S. E. 182 (1S97)], but it is held to notice that the funds do not belong to him [Smith v. Security Bank \& Trust Ca, 196 Ark. 685, 119 S. W. (2d) 556 (1938) ; Cady v. South Omaha Nat. Bank, 46 Neb. 756, 65 N. W. 906 (1896) l.

28. 5 Zollaran, Law of Banks \& B.inkrng (1936) \&3198.

29. Tiffany, Banks \& Banting (1912) 144; Huffeut, Liahility of a Bants to the Maker of a Check for the I'rongful Dishonor Thereof (1902) 2 CoL. L. REv. 193. 
of the bank is the duty to protect the title of the depositor. ${ }^{30}$ In this respect the bank cannot set up for its own benefit an adverse title to clefeat any attempt by the nominal depositor to withdraw the deposit or to draw cliecks on the money, in the absence of such an assertion by an attaching creditor or the true owner of the fund. When the bank has no notice from rival claimants, it must recognize the right of the depositor to the funcls. ${ }^{31}$

Duties Owed Equitable Owner of Deposit. Despite the rationale that the contract between the depositor and the depositary obligates the latter to the depositor, and that the bank must recognize the demands of the customer by honoring his checks up to the amount of the deposit or by allowing him to withdraw the money, the bank is also liable to the real or equitablese owner $^{33}$ of the deposit, regardless of the name under which the deposit was made. ${ }^{34}$ This conflict between the principles of contracts and the principles of property is reconciled by referring to the right of the real owner as equitable, ${ }^{35}$ or by referring to the duty of the depositary to pay to the rightftul owner on demand, where in equity or good conscience it should be so paid, as quasi-contractual. ${ }^{36}$ The rule that a depositary has a general lien upon all monies in its possession belonging to the depositor is said not to impinge upon the right of an equitable owner to assert a claim to part or all of the deposit, ${ }^{37}$ because the depositor has only legal title. The fact that the nominal depositor's right against the bank may be garnished in an action against him on his debt is said not to be inconsistent with the protection of the equitable owner's equitable rights. ${ }^{38}$ If the depositor was in wrongful pos-

30. Albro Co. v. Union Dime Sav. Inst., 15 App. Div. 351, 44 N. Y. Supp. 150 (1st Dep't 1897).

31. Penn. Title \& Trust Co. v. Real Estate Loan \& Trust Co., 201 Pa. 299, 50 Atl. 998 (1902). The bank is often said to be estopped from denying the depasitor's right to the fund on its own initiative. City Nat. Bank of Phila. v. Montrose Industrial Bank, 29 F. Supp. 566 (D. C. 1939) ; First Nat. Bank of Lock Haven v. Mason, 95 Pa. 113, 40 Am. Rep. 632 (1880).

32. The terms "real" and "equitable" are used synonomously to denote the party to whom in equity the deposit belongs. Thus, the "real and equitable" owner might be the person from whom the money was stolen, the principal, the cestui cue trust, the donce of a gift by deposit and others in similar circumstances.

33. Or to his assignee. McGuiness v. Bank of New South Wales, 1 N. S. W. 1. R. 97 (1880) (saving acc't).

34. 1 Morse, Law of Banks \& Banking (6th ed. 1928) §343. The right of the equitable owner to the funds is best exemplified in Falkland v. St. Nicholas Nat. 13atk, 84 N. Y. 145 (1881), where the principal-himself holding the money as trustee-gave it to his agent to deposit in the agent's own name in the defendant bank. The bank attempted to apply the funds to the indebtedness of the principal. Because the moncy ultimately belonged to the cestui que trust, the agent was granted recovery against the bauls.

35. ThFany, Banks \& Banking (1912) 41.

36. Compare Arkansas Nat. Bank v. Martin, 110 Ark. 578, 163 S. W. 795 (1014).

37. 1 Morse, LAw OF BANks \& Banking (6th ed. 1928) §343.

38. Sliman \& Co. v. Hemperly (Hemperly, Intervener), 184 La. 969, 168 So. 718 (1936). 
session of the money, or if the deposit itself either in the name of the rightiul owner or in the name of a third person was an unauthorized act, astrust is often said to be impressed by the unlawful act of the depositor, 39 and the bank is then under the duty to hold the money in trust for the real owner. ${ }^{\text {to }}$

The right of a claimant to his equitable share of the deposit in the name of a third person may now be asserted at law or at equity in the Lnited States. ${ }^{41}$ However, English law courts refuse to recognize the right of the true owner to recover in a legal action against the depasitary.42 The view: of the English law courts is that the depositary may not dishonor the customer's drafts, or deny the order of the customer, for any reason other than some sufficient one resulting from the action of the customer himself. ${ }^{43}$ However, the English equity rule necessarily recognizes the equitable right of the true owner to trace and to recapture his funds. ${ }^{4}$

Duties of Bank to Customer upon .Asscrtion of Adzerse Claim. In adlition to the general duties owed to its customers, the depositary incurs certain duties and liabilities upon the assertion of an adverse claim, particularly those owing to the nominal owner of the account. Any duty the bank may owe the customer not to disclose the state of the customer's account to strangers, is rather indefinite and undefined, ${ }^{45}$ but the bank will probably not he ledh liable for revealing to the adverse claimant the hank's obligation to the customer. ${ }^{46}$

Although the authorities are in conflict, it appears that in some jurisdictions the bank will be held to an affirmative duty to determine whether the claim advanced against the deposit is valid. ${ }^{47}$ Under this principle the lank:

39. 1 Bolles, Modern Law of Baxking (1907) 489; Brogan v. Kreins, 116 Kan. 506, 227 Pac. 261 (1924).

40. As long as the money in the bank can be identilied as a product of the original money, the right of the equitable owner to the funds ean be asserted. Banque Buge v. Hambrouck, L. R. 1 K. B. 321 (1921). For the various theories applied to tracing misappropriated funds, deposited with other monies belonging to the customer, aiter some withdrawals had been made, see 3 Scorr, Trusts $(1930) \$ \$ 515,517$.

41. I Mtorse, Law of Banks \& Bankmg (oth ed. 1923) \$343; First Nat. Banls of Auburn v. Eastern Trust \& Banking Co., 108 Me. 79 , 79 Atl. 4 (1911). Put of. Rhinshart v. New Madrid Banking Co., 99 Mo. App. 381,73 S. IV. 315 (1903).

42. 1 Morse, Law of Baxks \& Binkisg (cith ed. 192\$) $\$ 343$; Sims v. Pond, 5 Bar. \& Ad. 389, 110 Eng. Rep. 834 (K. B. 1833).

43. 1 Grant, Banking (1873) 148 .

44. 1 Morse, Law of Banks \& Banking (6th ed. 192\$) \$343.

45. See Hardy v. Veasey, L. R. 3 Ex. 107,112 (186S). The fact that none of the recent American cases discuss that question compels an inierence that the banls is nat liable for such a disclosure.

46. Tassell v. Cooper, 9 C. B. 509,137 Eng. Rep. 090 (C. P. 1850 ), in which action a count alleging the breach of a duty not to expose the state of the customer's account was abandoned, after Presiding Judge Maule, had stated that it probably was nut sustainable.

47. It is stated that upon receipt of notice of a bons fide claim, the hank must talie the necessary steps to protect the custumer. Miller $v$. Bank of Washington, $170 \mathrm{~N}$. $\mathrm{C}$. 
must act at its peril in all adverse claim actions. Upon it is thrown the burden of determining the validity of the claim, and the legality of its actions will depend upon subsequent determinations of the rights of the claimant. However, the bank's duty to test the validity of the claims advanced is often couched in terms of "sufficient evidence" 48 produced by the third party claimant, or of a "well founcled" claim, ${ }^{40}$ or of a claim made in "good faith." ro But accompanying these standards is the often asserted duty of the bank to allow an adverse claimant a reasonable time to stubstantiate his claim, following the bare notice to the bank of the claim. ${ }^{51}$ Thus, it would seem that the bank would have to react to all adverse clains in the same manner, regardless of whether they are formally or informally advanced by the claimant himself, or a third party, or whether they are or are not supported by evidence. The sole duty then left owing to the customer in regard to the determination of the validity of the claim $^{52}$ is the duty to recognize the adverse claim only during a reasonable time, unless legal proceedings have been started in the interim by the claimant to determine the rightful ownership.

If the bank does decide the issue of the equitable ownership of the funds by a payment to the adverse claimant, it subjects itself to liability to the customer upon proof of his superior right to the funds. in fact, is said to act at its own peril if it takes any affirmative action in determining for itself the rightful owner following the assertion of an adverse claim; ${ }^{54}$ payment to either of the.contesting parties can subject it to subsequent legal action. Upon receiving notice of the adverse claim, the bank's primary duty to the customer is to exercise diligence in notifying him of the advancement of the claim. ${ }^{55}$ Thus, a bank was held liable for dishonoring a customer's check when it did not make a reasonable attempt to locate the customer. ${ }^{50}$ If, after notice, the customer fails to appear to

152, 96 S. E. 977 (1918). Note particularly the dissenting opinion in which it is stated that the bank cannot ignore its duties to its customers merely because a stranger claitus the funds without any proof of the nature of the claim.

48. Minty, Law Relating to Banking and Foreign Exchange (1931) 45.

49. 1 Morse, LAw of BANKs \& Banking (6th ed. 1928) § 342 .

50. Ford v. Ames Nat. Bank, 196 Iowa 958, 195 N. W. 742 (1923).

51. 5 Zollman, Law of Banks \& Banking (1936) §3198.

52. It is to be noted that mere notice to the bank of the equitable right of the true owner of the funds, without an accompanying demand for the funds is not stuficient to establish a valid adverse claim [Wainwright v. Marine Nat. Bank, 72 Pa. Supcr, 221 (1919)], unless such notice is information of the wrongful deposit or the misappropriation of the funds [Davis v. Panhandle Nat. Bank, 29 S. W. 926 (Tex. Civ. App. 1895)].

53. Ford v. Ames Nat. Bank, 196 Idaho 958, 195 N. W. 742 (1923); see Pettey v. Dunlap Hardware Co., 99 Ga. 300, 25 S. E. 697 (1896).

54. 1 Bolles, Law of Banking (1907) 481; 1 MORSF, Law of Banks \& Bankind (6th ed. 1928) 792.

55. Jaselli v. Riggs Nat Bank, 36 App. D. C. 159 (1911); see Cole v. Canadian Bank of Commerce, 115 Ore. 456, 239 Pac. 98 (1925).

56. Jaselli v. Riggs Nat. Bank, 36 App. D. C. 159 (1911). 
defend the action brought by the adverse claimant or one claiming through him, the bank is required to protect the depositor by asserting his right, liut the defense advanced by the depository need not be a "strenuous and persistent contest." 57

Although the effect of an assertion of an adverse claim upon the general duty of the drawee bank to honor the checks of its customers is one of the most important phases of the entire adverse claim prollem, that question remains perplexing and unsettled, with many of its facets yet to he litigated or even to be comprehensively discussed. In the alisence of statutory regulation, the drawee bank is generally held to the duty of honoring checks of its customers up to the amount of the deposit, and is subject to an action for slander of credit damages upon a wrongful dislunor. It follows naturally that unless a valid adverse claim has been advanced, the bank may with impunity honor the checks of its depositor." Conversely, if a valid adverse claim has been advanced, the bank may without risk dishonor a customer's check if it exceeds any funds remaining after the stum claimed against has been set aside.59 Such generalizations, however, offer little solace to the bank, for the validity of the adverse claim is determined only after sulsequent litigation. The action which a bank must adnpt following the assertion of an adverse claim which later litigation proves to he invalid, ${ }^{60}$ is very perplexing. The specific issue has seldom been faced by the courts, although such situations have occasionally arisen. For this reason it may be assumed that where an adverse claim which later proves to he invalid is asserted, the bank may, to protect itself, dishonor its customer's checks, if it has made no payment to the adverse claimant. This conclusion is further fortified by the maxim that the bank, if it attempts to decide the adverse claim problem for itself, acts at its peril. However, a few cases that seem to touch on the

57. Detroit Savings Bank v. Burrows, 34 Mich. 153, 159 (1876). Thus, the hant: is not liable for defaulting in a garnishment action, althugh it kntws that a third res= son is the equitable owner, if the third persom wbtains lnwwledge of the garnishment presceedings in time to intervene. Randall $v$. Way, 111 Mas. 506 (1873).

58. Barnard v. First Nat. Bank of Newpyint, o1 Ind. Aly, 634, 111 X. E. 451 (1916). In this case, it was held that a valid adverse claim had nut heen advanced, because, although the depositor was alleged to have ubtained the money through a fratudulent sale of stock, the claimant had not rescinded the transaction by a return of the stost: certificates and hence had no claim to the money.

59. See France Milling Co. v. Fïrst Nat. Eank of Cobleskill, 138 App. Div. G4, 122 N. Y. Supp. 736 (3d Dep't 1910).

60. "It seems fairly obvious, if the situation involves a clicoling accoumt, that a refusal by the bank to comply with the demands of its depusitors on the strength of such notice, renders the bank liable for wrongful dishonor in a suit by the depositor ii the adverse claim is ultimately proved to he without merit." Comment (1930) 30 CizL. L. REv. $88, n .12$. Query: Is it not equally as olwious that upun receipt of nutice of an adverse claim the bank is under a duty to retain the custumer's funds for a reasonable length of time, regardless of the validity or invalidity of the adverse claim? If the conclusion reached therein is universally and "obviously" correct, banks are indece in an extremely perilous position. 
problem indicate that the bank may be held for wrongful dishonor if the claim subsequently proves to be invalid. ${ }^{11}$ The wisdom of such a conclusion is questionable since it forces the bank to operate at its peril in all cases wherein the validity of the adverse claim is not certain.

The failure of the courts to establish a consistent rule regulating the honoring of checks in adverse claim situations, is a resultant of their reluctance to recognize a distinction between the duty of a bank to honor customer's checks, and rights of the claimant or customer to the balance of the account.02 Recognizing the general doctrine that the equitable owner is entitled to the funds, courts generally turn the question of whether an action for slander of credit will lie upon the determination of equitable ownership. Thus, courts may state that the depositary bank is at peril if it attempts to decide the adverse claim issue for itself; yet they reiterate that the bank must honor all checks drawn by the customer upon funds belonging to him. Following these principles, a fortiori, when faced with the problem of honoring checks, the bank must determine for itself the equitable ownership of the funds, and hence is often forced into a perilous situation where it may be subjected to double liability. The need for a separate treatment of these distinctly different fact situations becomes apparent when one considers that the time element assumes much importance in the checking transaction; whereas generally it has less bearing upon a demand for the balance. As a practical matter, the bank may frequently avoid dishonoring a check by returning it to the clearing house with a request that it be presented on the following day, or by requesting the party making a counter presentation to return the following day. The bank can then demand that the claimant take legal action to protect it; if no legal process is served upon the bank, the bank maly recognize the nominal customer's right to the funds on the grounds that the laches of the claimant in failing to take legal action within a reasonable length of time, deprived him of his rights against the bank. However, even this

61. In Wildenberger v. Ridgewood Nat. Bank, 230 N. Y. 425, 130 N. E. 600 (1921), after the adverse claim advanced by his wife for one-half share of the accoutut had becul withdrawn, the customer successfully brouglit an action against the bank for injury to his credit standing as a result of the dishonoring of four checks. Justice Cardozo declared that the bank had set the risk of adverse claims against the risk of broken contracts and consequently must suffer the results of its wilful action. This decision, if followed, would place the bank in the unenviable position of being forced to jutlge the validity of the adverse claim, with a damage action as penalty for a wrong guess. See also Barnard v. First Nat. Bank of Newpoint, 61 Ind. App. 634, 639, 111 N. E. 451 (1916). In Jaselli v. Riggs Nat. Bank, 36 App. D. C. 159 (1911), the court rulcd that if a claim is made in good faith and if the bank exercises diligence in notifying the customer, the bank may withhold payment. Cf. Pascagoula Nat. Bank v. Eberlciu, 161 Miss. 337, 131 So. 812 (1931) ; Plunkett v. Barclays Bank, Ltd., [1936] 2 K. B. 107, 1936, 1 All E. R. 653. L. R. 2 K. B. 107 (1936).

62. None of the literature discusses the adverse claim problem in terms of these two distinct and separate legal questions. 
procedure is unsatisfactory for the standard of reasonable time, a jury question, is much too varying to be dependable.

When the bank has wrongfully delivered the funds to the adverse claimant, thus having independently determined the issue of ownership, it seems rather clearly settled that an action by the customer for a wrongiul dishonor of his check will lie. ${ }^{63}$ Thus, in Jasclli $z$. Rigys . Yalional Bank, when the bank paid out money claimed by the depositor's brother without notifying the depositor, the latter was granted slander of credit damages. The court emphasized the failure of the drawee bank to exercise diligence in notifying the customer of the adverse claim. These legal principles of the American courts may be contrasted with the view taken ly the English courts that the contract between the bank and the customer is of superior importance and that a claim to the deposit will not justify the dishonoring of a check, even though the money may have been received by the depositor without authority. ${ }^{65}$ In the Jasclli case, the court alsu distinguished between checks drawn prior to and those drawn after notice by the bank to the customer of the adverse claim, reasoning that a cause of action for slander of credit damages may not lie for the dishonor of ehecks drawn after notification, but that the bank acts at its peril in dishonoring if the clieck has been drawn before notice of the adverse claim reached the customer. The bank is thus forced to hazard a subjective determination of the validity of the claim, often without the necessary pertinent facts, subject to the extreme penalty of liability if it errs in its judgment.

The right of the customer to the balance after the assertion uf an advers: clain depends, of course, upon the determination uf the legal ur equitable ownership of the fund, and until such judicial determination has been marle, the bank can meet the demand of the customer for the lalance only at the risk of a similar payment to the claimant if the latter's right to ownership, is subsequently proved. However, the bank cannot lue furced, under this threat of double liability, to withhold the funds from the nominal depositor or to dishonor the customer's checks for an unlimitenl length of time. The right of the adverse claimant to demand that the lank retain the funds is said to exist only for that length of time which is sufficient to provide the claimant with a reasonable opportunity to take legal step's to assert his claim. ${ }^{\text {6n }}$

63. Jaselli v. Riggs Nat. Bank, 36 App. D. C: 159 (1911); Patteron v. Marius Nat. Bank, 130 Pa. 419, 18 Atl. 632 (1889).

64. Jaselli v. Riggs Nat. Bank, 36 App. D. C. 159 (1911).

65. I Hart, Law of Bankina (4th ed. 1931) 413; Tasell v. Cugler, 9 L. I\%. 50\%, 137 Eng. Rep. 990 (C. P., 1850). The court in Funtaine-Eenson v. Parr's Banling Co. 12 T. L. R. 121 (C. A. 1895), refused to grant 3 interim injunetion restraining the bank from honoring drafts drawn by the custumer, claiming that to issue such an order would be to interfere between the bank and its customer without an apnearance by the latter.

66. 5 Zolraran, Law of Banks it Banking (1936) \$3198. "Anyune claiming money deposited in a bank to the credit of another ought to be required to exercise the 
It must be noted that the test of a "reasonable period of time" leaves the bank in a relatively insecure and uncertain position, for it cannot determine whether it has been relieved of possible liability until the peculiar circumstances of each case have met the subjective examination of the jury. Becaluse of this constant threat of double liability, very few banks will probably take advantage of the possible release from liability that might be obtaincd as a result of the claimants failure to take legal action within a reasonable period of time.

Rights, Dutics and Pozers of Adverse Claimant to Deposit. Necessarily, the rights and duties of the adverse claimant are converse to those of the nominal depositor of the funds. Prior to adequate notice ${ }^{67}$ that the funds are alleged to belong to the adverse claimant, and to be in danger of misappropriation, the bank owes no immediate duty to any potential adverse claimant. However, upon the adequate assertion of the adverse clatim, dutics and obligations owing by the bank to the claimant immediately arisc. Thic bank is charged with the responsibility of holding the money for a reasonable length of time pending the determination of the validity of the claim. ${ }^{\text {as }}$ After proper notice has been given to the bank, it may not assert its own claim against the nominal depositor to defeat the superior equitics of the adverse claimant. ${ }^{69}$

In the absence of statutory regulations, ${ }^{70}$ notice of the adverse claim places the bank under the duty of dishonoring checks drawn by, or refusing dcmands for the balance by the nominal depositor, even as against the attaching creditors of the depositor, to the extent that the deposit has not been depleted at the time the claim is advanced, or to the extent that the bank has not already committed itself in reliance on the depositor's apparent title. ${ }^{71}$

same diligence in taking legal steps to assert his claim thereto that a reasonably prudent and diligent person would exercise in attaching the property of his debtor when satisfied that such debtor is about to make a fraudulent disposition of his property, or to remove same from the state." Drumm-Flato Comm. v. Gerlach Bank, 107 Mo. App. 426, 434, 81 S. W. 503 (1904). Inasmuch as legal proceedings may be instituted almost at will, the reasonable length of time may well be so short as to give the clainant little or no leeway. Sce the dissenting opinion in Miller v. Bank of Washington, 176 N. C. 152, 96 S. E. 977 (1918) wherein Judge Walker states that a half hour is sufficient tinte to obtain a writ of attachment, and that consequently the bank is not liable to the claimant although it had paid the depositor only a few hours after it had been notificel of the claim.

67. See note 52 supra. See p. 1008 infra for statutory requisites of adecutute notice.

68. Huff v. Oklahoma State Bank, 87 Okla. 7, 207 Pac. 963 (1922).

69. First Nat. Bank of Auburn v. Eastern Trust \& Banking Co., 108 Me. 79,79 Atl. 4 (1911); Whitecotton v. Wilson, 197 S. W. 168 (Mo. App. 1917).

70. See p. 1007 infra.

71. 5 Zollasan, Law of Banks \& Banking (1936) §3198; Armour-Cudaliy Packing Co. v. First Nat. Bank of Greenville, 69 Miss. 700, 11 So. 28 (1892); Firazier v. Erie Bank, 8 W. \& S. 18 (Pa. 1844); see Kassow v. Integrity Trust Co., 19 Pa. D. \& C. 159 (1933). 
This duty to the adverse claimant remains even when the nominal lepositur brings legal action against the bank for refusing tu return the funls. Therefore, payment by the bank to the sheriff in an action of replevin brought by the customer does not relieve the bank of lialility to the rightful owner why has properly presented his claim.'2 Thus, in the L'nited States, the claimant is legally protected against the depletion of the funds in contruversy following the advancement of the adverse claim. ${ }^{73}$ If the atverse claimant can subsequently prove that he is the rightful wwner of the money, ${ }^{\text {it }}$ he is entitled to recover it from the bank, ${ }^{\text {, }}$ when the funds to which he uriginally: claimed ownership can be traced to the deposit frum which he is seding to obtain redress. ${ }^{76}$ Howerer. an adverse claim cannut he assurted to enalle a creditor to secure payment of a debt owed to him by the depmsitor.7t Lut bank deposits are subject to attachment or garnishment ly crelitors of the nominal depositor. In such an action the adverse claimant can jrotect himseli against possible payment to the plaintiff in a garnislment action, ly jutting the bank on notice of the adverse claim, even if such notice is given after the garnishment process has been served upon the depositary. ${ }^{\text {is }}$ Payment tu the ertelitur in such circumstances is looked upon as use of a thirl person's money t." pay the obligations of the debtor. ${ }^{\text {a }}$ After proper notice of the garnishment has reached the garnishee bank, it is placed undur the duty of revealing the adverse claim in its answer. A failure to do su, which action may firéclude the claimant from asserting his clain in the garnishment action, renler. the bank directly liable to the real owner for the sum paid out in the garnishment proceedings. ${ }^{80}$

72. Arkansas Nat. Bank v. Miartin. 110 Ark. 578, 163 S. W. 715 (1914).

73. He may depend upon notice to the bank protecting the disyuted funds unly if he exercises diligence in instituting legal process within a reasonable time thercafter. See p. 997 supra. Such protection is not granted in England, huwever, unless the hanls is restrained by legal process from affecting the denosit. PAGEr, LAw os BAswiris (4th ed. 1930) 188; Tasell v. Cooper, 9 C. B. 509,137 Eng. Rep. 990 (C. P. 18501.

74. Although the adverse claimant must usually hear the burden of establiching hi, superior right as true owner of the deposit, the hank which honors the demand of th: nominal depositor after notice of misappropriation, hears the hurden uf jroving that it

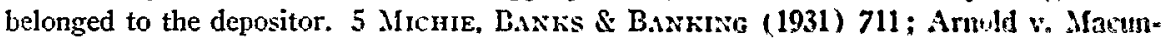
gie Savings Bank, $71 \mathrm{~Pa} .287$ (1872).

75. Arkansas Nat. Bank v. Martin, 110 Ark. 578,163 S. W. 795 (1914); Hemuhill v. Yerkes, 132 Pa. 545, 19 Atl. 342 (1890) ; Stair v. York Nat. Bank, 55 Pa. 344 (1\& 8 ).

76. Van Alen v. American Nat. Bank, 52 N. Y. 1 (1873); IValsh v. Nat. Ireads ay Bank, 11 Misc. 249, 32 N. Y. Supp. 734 (C. P. 1895), aff'd, 13 Mist. 3, 33 Х. Y. Supy. 998 (C. P. 1895) ; Hungerford v. Curtis, 43 R. I. 124,110 Atl. 650 (1920), 12 A. L. K. 1040,1048 (1921).

77. See Hastings v. First Nat. Banle of Corning, 170 Ark 939, 281 S. W. 905 (1926).

78. Bessemer Savings Bank v. Anderson, 134 Ala. 343, 32 So. 716 (1902); Farmers" \& Mechanics' Nat. Bank v. King, 57 Pa. 202 (1\&(8).

79. Bank of Northern Liberties v. Jones, $42 \mathrm{~Pa}$. 536 (1862), aff'd sthl num. Juntes v. Bank of Northern Liberties, $4+$ Pa. 253 (1863).

80. Bessemer Savings Bank v. Anderson, 134 Ala. 343, 32 So. 716 (1903). 
Effect of Payment by Bank Prior to Judicial Detcrmination. Payment by the bank to either the adverse claimant or the customer following adecluate notice or demand upon the depositary bank does not per se constitute a valid defense for the bank. However, following the analogous law of bailments, ${ }^{81}$ payment of the funds to the true equitable or lawful owner will protect the bank, even if sucl payment is made upon the initiative of the bank. ${ }^{82}$ The same rules concerning the availability of the defense of payment apply, even if such payment is pursuant to court order. Unless made to the true owner, ${ }^{83}$ payment under judgment will not serve as protection to the bank against actions brought by persons not a party to the original proceedings. ${ }^{84}$ Thus, the fact that a bank pays the deposit purstint to a judgment against it as garnishee of the depositor's husband is not a defense to an action against it by the depositor. Not having been a party to the action, the depositor may recover from the bank upon proof that the money is hers. ${ }^{85}$

In the usual adverse claim situation, payment by the bank to either the depositor or the adverse claimant prior to a judicial determination of ownership places the bank under the risk of being forced to make a second payment to the rightful owner if it has guessed wrong. The bank must then seek redress from the one to whom it first gave the money. In most cases in which payment is made either to the adverse claimant ${ }^{80}$ or the nominal

81. Elliotr, Bailments (2d ed. 1929) 22, n. 47. See Comment (1930) 30 Col. L. Rev. 86, 89, where an analogy between bailment for hire and bank deposits is drawn.

82. Tiffany, Law of Banks \& Banking (1912) 50; Brown v. Kinsley Exch. Bank, 51 Kanl. 359, 32 Pac. 1113 (1893).

83. See Walsh v. Nat. Broadway Bank, 11 Misc. 249, 32 N. Y. Supl. 734 (C. P. 1895), aff'd, 13 Misc. 3, 33 N. Y. Supp. 998 (C. P. 1895).

84. 1 Morse, Law of Banks \& BANking (6th ed. 1928) 793; Spaulding Mfg. Co. v. Chaudoin, 87 Ark. 418, 112 S. W. 1087 (1908). But see Crumb v. Treiber, 4 Ohis, Dec. 492 (1879). In an action brought to prevent the bank from applying the deposit to the indebtedness of the nominal depositor, the consignee, the consignors obtaince a decree that the funds belonged to them. The depositor subsequently sued the bank for dishonoring three of his checks, but the decree was sail to constitute a good defense to the action by the depositor. The decision turned on the assertion that, intesuntech as the depositor had notified the consignors to pursue the money, he no longer hitd the right to draw checks on that fund in his namc. Hama v. Drovers' Nat. Banls, 194 1ll. 252, 62 N. E. 556 (1901).

85. Townsend v. Webster Five-Cent Savings Bank, 143 Mass. 147, 9 N. 1E. 521 (1887).

86. Banks correctly paid the funds to adverse claimants who were later adjudged to be equitable owners in the following cases: Bryant v. Century Bank of City of N. Y., 155 N. Y. Supp. 1010 (Sup. Ct. 1915), aff'd, 169 N. Y. Supp. 1086 (App. Div., 1st Dep't, 1918); Parks v. Knickerbocker Trust Co., 137 App. Div. 719, 122 N. Y. Supp. 521 (1st Dep't 1910) (not a checking account); White v. Bank of Angola, 130 Misc. 99, 223 N. Y. Supp. 508 (Sup. Ct. 1927) ; cf. Clark v. Saugerties Saving Bank, 62 Hun 346,17 N. Y. Supp. 215 (Sup. Ct. 1891) (savings account). The bank wrongfully paid invalid adverse claims in the following cases: Jaselli v. Riggs Nat. Bank, 36 App. D. C. 159 (1911) ; Ford v. Ames Nat. Bank, 196 Iowa 958, 195 N. W. 742 (1923) ; Patterson 
depositor, ${ }^{\text {st }}$ the liability of the bank turns upon the question of whether the recipient of the payment is the equitable owner, whether the issue is pused by the honoring of a checkss for a sum which comes within the disputer funds, or by the payment over of the entire balance. The mode ur quantum of the payment is not material. But where the hank justifies its payment of the funds not upon its own determination of the ownership, but under statutory provisions ${ }^{\mathrm{so}}$ or because of laches on the part of the adverse claimant in having failed to take action within a reasonable time, ${ }^{90}$ questiuns of ityuitable ownership may be unimportant. Pragmatically, if the bank does venture to pay the balance to one of the parties, it is more likely to pay the depositor. This disposition to favor the nominal depositor springs from the presumption that he is the owner of money deposited in his name. Moreuver, the bank, being generally better acquainted with the customer, may have more confidence in his claim, or feel there is greater uppurtunity fur redress if subsequently the payment is held to be wrongful.

\section{Problems Peculiar to the Varying . Adverse Cham Smuatums}

The unique problems of the first two classes of adverse claims, where the money in dispute is alleged to have been stolen from the claimant, or is in danger of being misappropriated contrary to the fiduciary cluty of the depositor, are generally those stemming from the wrongful dishonor of a depositor's check. As previously indicated, no consistent rules regulating the bank's duty to honor checks in the face of an asserted adverse claim

v. Marine Nat. Bank, 130 Pa. 419, 1s Atl. 632 (1889): of Bcssemer Savings Bants v. Anderson, 134 Ala. 343, 32 So. 716 (1902); Townsend v. Welster Five-Cent Savings Bank, 143 MLass. 147, 9 N. E. 521 (1887).

87. There seem to have been no cases litigated in which banks curructly jail the funds to the nominal depositors whom the banks assumcd to the the cquitable un ners. This fact is not surprising, for an adverse claimant would be unlikely to bring an action against the bank for having paid the depositor, with whom the presumftiun uf un nurship rests, unless he has substantial proof that the depusitur has no right to the fuml. On the other hand, there have been quite a few cases in which the bankis wrumginily paid the funds to the depositor after notice: Arkansas Nat. Bank v. Martin, 110 . Ark. 578, 163 S. W. 795 (1914); Valley Dank \& Trust Cu. v. Parthum, 47 Ariz 4ti, 50 P. (2d) 1342 (1936), rehcaring dinicd, 48 Ariz. 87,59 P. (2d) 335 (1433); I'sth v. Whitten, 170 Mo. App. 108,155 S. W. 80 (1913); Whitecuttun v. Wilsun, 197 S. W. WS (Mo. App. 1917); McCarthy v. Provident Institution fur Savings, 159 Mass. 53, 34 N. E. 1073 (1S93) (savings account) ; Peter Adams Co. v. Nat. Shoe \& Leather Bants, 44 Hun 629,9 N. Y. Supp. 75 (Sup. Ct. 18S7); Miller v. Lank of Washington, 170 N. C. 152, 96 S. E. 977 (1918); First Nat. Bank of Wellsboruugh v. Bacle, 71 Da. 213 (1872).

8S. Of cases listed stipra note 87 , the bank wrongiully hunured the dcpusitur's chad: after it had received notice only in the Valley Bank \& Trust Co., Whitccollon, and Peter Adams cases.

89. Nat. City Bank v. Continental Nat. Bank \& Trust Co., \&3 F. (2d) 134 (C. L. A. 10th, 1936).

90. Huff v. Oklahoma State Bank, 87 Okla. 7, 207 Pac. 963 (1922). 
are discernible. The further question of whether the bank has recourse against the adverse claimant if his claim subsequently proves to be invalid, remains unlitigated.

Protective Adverse Clains. This group of adverse claims which are asserted to preserve one's equitable rights to the funds or to secure redress through the equitable funds of an obligor, presents an individual problem which is not present in the other types of adverse clain cases. Here garnishment or attachment process, singularly different from a garnishment action which is started by the adverse claimant himself to secure the disputed fund, may be directed either against the nominal depositor or the adverse claimant. Where writ of garnishment or trustee process is serverl agrainst the depositary bank by a creditor of the nominal depositor, unless the creditor gave credit or sustained loss on the basis of the cleposit, the creditor has no better right to the funds than the depositor. ${ }^{21}$ Thus, when informed of the claim of the equitable owner, the bank is uncler the daty to deny the right of the creditor to the debt, and the court in adjudicating the garnishment controversy must decide the rightful owner. ${ }^{22} A$ finding that the moncy belongs to the adverse claimant defeats the garnishment action..$^{03}$ In such cases the garnishee bank may present the evidence of the equitable owncr," or the equitable owner may be allowed to enter his own defense. 05

Creditors of the equitable owner of the deposit may bring garnishment action against the depositary, and after such process is served upon the bank, the bank may not recognize any demands by the nominal owners until the true owner is determined by the court. ${ }^{96}$ To restrain the bank and to put

91. Skilman v. Miller, $70 \mathrm{Ky} .428$ (1870) ; Hemphill v. Yerkes, $132 \mathrm{~Pa} .545,10$ Atl. 342 (1890).

92. Morrill \& James v. Raymond, 28 Kan. 415, 42 Am. Rep. 167 (1882); Brandon v. Interstate Life \& Accident Ins. Co., 149 Miss. 808, 115 So. 888 (1928); cf. Plunkett v. Barclays Bank, Ltd., L. R. 2 K. B. 107, (1936) 1 A. \& E. 653, which alsolved the bank from liability for having followed a garnishment order, on the grounds that al though it knew the account to be a fiduciary one, it did not know the identity of the equitable owner. It has been held that a failure to reveal the adverse claim, which dereliction precludes the claimant from asserting his right in the garnishment action, renders the bank directly liable to the real owner for the sum paid out in the garnishment proceedings. Bessemer Savings Bank v. Anderson, 134 Ala. 343, 32 So. 716 (1902).

93. Sliman \& Co. v. Hemperly, 168 So. 718 (La. App. 1936); Commonwealth v. De Rose, 26 North. Co. Rep. 375 (Pa. 1938); see Cunningham v. Bank of Nampa, 13 Idaho 167, 88 Pac. 975 (1907).

94. Bank of Northern Liberties v. Jones, $42 \mathrm{~Pa} .536$ (1862), aff'd sul nom. Jones v. Bank of Northern Liberties, $44 \mathrm{~Pa} .253$ (1863).

95. Commonwealth v. De Rose, 26 North. Co. Rep. 375 (Pa. 1938). In Levin v. Lerner, 290 Mass. 294,195 N. E. 387 (1935), the adverse claimants appeared under a Massachusetts statute providing that if a person claiming money in the hands of a trustee enters an appearance in a trustee process action, he shall be admitted as a party to the action.

96. Potter v. Whitten, 170 Mo. App. 108, 155 S. W. 80 (1913) : Eau Clairc Nat. Bank v. Chippewa Valley Bank, 124 Wis. 520, 102 N. W. 1068 (1905). 
it on notice of an adverse claim asserted through the equitable owner, however, the allegations in the garnishment action must clearly state that the money deposited in the customer's name actually lielongs to the garnisher. ${ }^{0}$ If the writ is not directed properly, the bank can volunteer information concerning the equitable rights of the garnishor in its deposits at its own peril; the garnishment writ does not then absolve it from liability. 95 The force of the garnishment or attachment writ is indicated ly the fact that even if the nominal depositor had, prior to the service of the writ, drawn a clecl: for the amount in favor of the equitable owner, the creditur hringing a garnishnent action has a right to the funds superior to the equitable owner ${ }^{83}$ and to a subsequent holder in due course. ${ }^{100}$

Deposits in the Name of a Third Person. Adverse clains springing from the deposit of money in the name of a third person are unique primarily because they present the question of whether the deposit constitutes a valiu gift to the nominal depositor. Even though the deposit is marle in the name of a third person, the depositor is entitled to the funds if he can show that he did not intend a gift or a trust, and that the money remained under lis equitable ownership."11 Thus, where the plaintiff has depositel moncy in the name of his mother, he may recover it from the bank upun her death if he can show that he merely intended the money to pass to her in cast of his death. ${ }^{102}$ The agreement between the depositor and the hank is controlling, and the bank must give effect to a stated intention that the crediting of the money to a third person should not impair the depositor's right to withdraw the money. ${ }^{103}$

The rights of the person in whose name the deposit is made, are governeal by similar rules. Like other nominal depositors who made the deposit in their own names, the person in whose name the deposit rests may lo assumed, in the absence of adverse clains, to have a right to withdraw it, althumgh the money is deposited by another ${ }^{104}$ however, mere deprsit in his name does not necessarily mean that he has the equitable ownership of the de-

97. German Eank v. Himstedt, 42 Ark, 62 (1883).

98. Pascagoula Nat. Bank v. Eberlein, 161 Miss. 337, 131 So. 812 (1931).

99. Catanzaro \& Sons v. Hellman Commercial Trust \& Savings Rank, $231 \mathrm{~Pa}$ fto, 126 At1. 812 (1924).

100. Rackwell v. Silvara, $45 \mathrm{~Pa}$. Super. 505 (1911).

101. Tiffany, Law of Banrs \& B.nNming (1912) 51-52; d. Viets v. Cinin Vat. Bank, 101 N. Y. 563, 5 N. E. 457 (1886).

102. Roughan v. Chenango Valley Savings Bank, 158 App. Div. 786, 144 X. Y. Supp. 508 (4th Dep't 1913), aff'd. 216 N. Y. 696, 110 N. E. 1049 (1915).

103. 1 Bolles, Law of Banking (1907) 482. "A depositor contracting with a bast: for the care of his money can control his funds until he has disposed of them, no matter in what name the account is kept, so long as it is understond th be his acciunt, and has not been put beyond his control by some act which he cannot reroke." I lavis v. Lenaw County Savings Bank, 53 Mich. 163, 166. 1s N. W. 034 (18S4).

104. Hastings v. Hugo Nat. Bank, 81 Okla. 189, 197 Pac. 457 (1121); Foril v. Ames Nat. Bank, 196 Iowa 958, 195 N. W. 742 (1423). 
posit. ${ }^{105}$ The deposit must unquestionably be for his benefit with a necessary showing of acceptance or a presumption of an acceptance before the person in whose name the deposit is made can assert a superior right to the funds. Once such acceptance can be shown, the bank cannot deny its liability to the nominal depositor. ${ }^{100}$ In cases of a conflict between the creditors of the actual and nominal depositors, the fund may be successfully garnished by those claiming through the equitable owners of the funds; in these fact situations, the courts treat the action as if between the nominal depositor and the adverse claimant. ${ }^{107}$

\section{Remedial Actions to Resolve Adverse Claim Issues}

Because the adverse claim problem is a recurring one for banks, the most perplexing remedial questions quite naturally deal with the legal protection available to the depositary when faced with the claims of both adverse claimant and nominal depositor. The need for sufficient safeguards to enable banks to handle adverse claims with some degree of certainty and security, must take precedence over the desire to assist individual adverse claimants or nominal depositors in advancing their claims.

Protection for the Bank - Equity and Statulory Intcrpleadcr. When faced with a "matter of doubt" 108 as to whom the funds in question belong, the bank may be able to resort to the equitable remedy of interpleader to compel the adverse claimant or the depositor to answer the claims of the party bringing the action against the bank. ${ }^{100}$. Interpleader is the logical technicuc to protect the bank from unnecessary litigation and from the hazard of being forced to settle independently a controversy between two other parties. But use of the equitable interpleader has to a large extent been discouraged ${ }^{110}$ by the imposition of very strict requisites which must be met before a motion for interpleader will be granted.111 In the absence of an applicable statutory remedy, denial of the bank's motion to interplead the other claimant to the fund compels the bank to defend itself against double liability in the law

105. Tiffany, Law of Banks \& Banking (1912) 51-52.

106. People v. State Bank of Fort Edward, 36 Hun 607 (N. Y. 1885), aff'd, 102 N. Y. 740 (1886). Cf. Wallis v. First Nat. Bank of Bluejacket, 117 Okla. 142, 245 Pac. 626 (1926), which held that an agreement between the bank and the actual depositor subsequent to the deposit would control the rights of the nominal depositor.

107. Albro Co. v. Union Dime Savings Inst., 15 App. Div. 351, 44 N. Y. Supp. 150 (1st Dep't 1897).

108. Bell v. Citizens Nat. Bank of Elkins, 122 W. Va. 312, 9 S. E. (2d) 143 (1940).

109. Foss v. First Nat. Bank of Denver, 3 Fed. 185 (C. C. D. Colo. 1880) ; Germatu Exchange Bank v. Comm'rs of Excise, 6 Abb. N. Cas. 394, 57 How. Pr. 187 (N. Y. 1879); see Note (1929) 60 A. L. R. 719.

110. German Exchange Bank v. Comm'rs of Excise, 6 Abb. N. Cas. 394, 57 How. Pr. 187 (N. Y. 1879).

111. See p. 1005 infra. 
courts. ${ }^{112}$ However, if interpleader is allowed, the bank has only to deposit the money in court and the opposing parties are brought in to determine their controversy; the bank's interest in the money thereupon ceases. ${ }^{113}$ Since the court secures jurisdiction over both the subject-matter and parties, ${ }^{114}$ its judgment becomes res adjudicata.

But the strict requisites which equity requires to be proved liefore a motion for interpleader is granted often become prohibitive. The bank must show not only that there are two or more parties asserting ${ }^{113}$ claims to the same fund, but also that the demands made upon the bank are supported ly well founded and substantial conflicting claims. ${ }^{115}$ The court must alco be convinced that there is no possibility of the bank's protecting itself from the hazard of loss by means other than the interference of the court. 117 Moreover, there must be no collusion between the bank and one of the parties to the action, and the action must not further the claim of either party to the fund. ${ }^{11 S}$ In addition to these requirements, it is sometimes stated that the adverse titles of the claimants must be connected or dependent, or liath derived from a common source, and that the bank must have incurred no independent liability to either of the claimants ${ }^{119}$ - stipulations which, if

112. Runkle's Adm'r v. Runkle's Adm'r, 112 Va. 28S, 72 S. E. 695 (1911).

113. Walsh, Treatrse on Equiry (1930) 562; see Detroit Savings Bank v. Haint;, 128 Xich. 38, 87 N. W. 66 (1901) ; Egbert v. Payne, 99 Pa. 239 (18\$1).

114. Phillips v. Suffolk Savings Bank, 219 Mass. 597, 107 N. E. 401 (1914) (cavings account).

115. The claimant must at the time of the motion for interpleader be prosceling tin enforce his alleged rights. German Savings Eank v. Friend, 20 N. Y. Supp. 434,4 N. Y. St. R. 400 (1S92); Lund v. Seaman's Bank, 20 How. Pr. 401 (18t1), aff'd, 23 How. Pr. 258 (1862).

116. Bedell v. Hoffman, 2 Pai. Ch. 199 (N. Y. 1830); German Exchange Pank v. Comm'rs of Excise, 6 Abb. N. Cas. 394, 57 How. Pr. 187 (N. Y. 1879); Cushrane v. O'Brien, 8 I. Eq. R. 241 (Ch. Ire. 1845).

117. Bedell v. Hoffman, 2 Pai. Ch. 199 (N. Y. 1830); Helene v. Curn Fischange Bank, 96 App. Div. 392, $\$ 9$ N. Y. Supp. 310 (1st Dep't 1904).

118. Helene v. Corn Exchange Bank, 9i App. Div. 392, 89 N. Y. Supp. 310 11-t Dep't 1904): Marvin v. Ellwood, 11 Paige 365 (Ch. N. Y. 184t).

119. Pomeroy sets out four essential elements which must be present licfure the cyuitable remedy of interpleader, independent of statutory regulations, may be secured. First, the same debt must be claimed by both parties against whom the interplealer is demanted. 4 Podreroy, Equity Jurisprumence (5th ed. 1041) \$1323. Sccond, the adver titles of the claimants must be connected or dependent, or buth derived from a commun source. $I d$. at $\$ 1324$. This second requirement of "privity" prevents interpleader from issuing where the title of each claimant was distinct and indenendent of the uther. Later cases have tended to relax this rule or ignore it cumpletely. Id. at $\$ 909$; First Nat. Bank of Portland v. Reynolds, 127 Me. 340, 143 Atl. $2(6,60$ A. L. R. 712 (14)3). Thirl, the person seeking the relief must not have nor claim any interest in the subject matter,

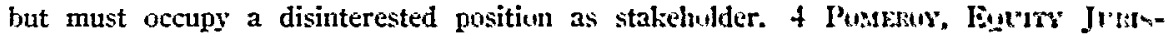
PRUDENCE $\$ 1325$. Fourth, the plaintiff praying for interpleader must have incurred nu, independent liability to either of the claimants. Id. at $\$ 1326$. Here tur, the rule has heen relaxed, so that in some jurisdictions interpleader will nut be denied unlens the litigatiun 
rigidly observed, serve to render the equitable relief of interpleader inaccessible to the bank in most adverse claim situations.

To a large extent, the common interpleader statute has removed the historical barriers and technicalities that have in the past prevented banks from seeking interpleader relief when an adverse claim to one of its deposits has been asserted. The New York statute, ${ }^{120}$ for example, provicles that in an action to recover money on deposit, if any person, not a party to the action, makes a claim to the same fund, the court may upon request by the bank make the claimants parties defendant. The court can then determine the rights of the parties to the action. The fund may remain on deposit with the bank until final judgment, drawing the same interest as other cleposits; or the deposit may be paid into court pending final determination of the action, and the bank, being no longer liable for the deposit, is not a party to the action. Under English statute, the only restrictions are that the applicant, having no interest in the subject-matter, cannot collude with one of the rival claimants, and must be willing to transfer the subject-matter to the court or dispose of it as the judge may direct. ${ }^{121}$

Protection for the Bank - Other Common Law and Equitable Remedics. Upon the assertion of the adverse claim, the bank to obtain protection may make a simultaneous offer to either or both the rival claimants to pay over the funds to whichever one will indemnify it. If either agrees to post a bond of indemnity fully protecting the bank, it can with comparative safety pay over the disputed funds. ${ }^{122}$ In fact, the bank may take the indemnity from both of the claimants and then decide to which party it clesires to pay the funds. ${ }^{123}$ As a practical matter, the bank probably will pay the funds to the nominal depositor if it can secure adequate indemnity from him. This preference for the depositor springs directly from the fact that the bank is certain that its liability to the adverse claimant will not exceed the amount of the sum claimed, and thus it can with relative certainty provide for sufficient indemnity from the nominal depositor to cover all possible payments to the claimant. On the other hand, if it pays the adverse claimant and the nominal depositor subsequently proves to be the equitable owner, the bank may be liable for slander of credit damages. In such cases the bank may

between the defendants will not finally determine the independent liabilities owed to rival claimants by the bank. First Nat. Bank of Portland v. Reynolds, $127 \mathrm{Me}$. 340, 143 Atl. 266, 60 A.L.R. 712 (1928).

120. N. Y. BANKING LAw $\S 134,6(a)$, (b), (c). This remedy is in addition to the interpleader provisions of Section 287 of the Civil Practice Act. See McKeown v. Bank for Saving, 26 Misc. 824, 56 N. Y. Supp. 1080 (Sup. Ct. 1899); N. Y. Trust Co, v. Braham, 126 Misc. 462, 213 N. Y. Supp. 678 (1926).

121. Walsh, Treatise on EQUity (1930) 568.

122. Bedell v. Hoffman, 2 Paige 149 (Ch. N. Y. 1830); German Exchange Bank v. Board of Comm'rs of Excise, 6 Abb. N. C. 394, 57 How. Pr. 187 (N. Y. 1879).

123. First Nat. Bank of Wellsborough v. Bache, 71 Pa. 213 (1872). 
not receive full protection, for the slander of credit damages may well exceed the indemnity furnished by the adverse claimant.

Upon the assertion of an adverse claim, the bank may find it feasilyle to wait until the adverse claimant takes legal action befure making any transfers of the money in dispute. ${ }^{124}$ This course of action may be undesiralule if it subjects the bank to the possibility of an action for wrongful dishonor of the customer's check in the interim. However, if it can successfully sidestep the necessity of honoring or dishonoring the custumer's check, the bank by inaction can force one of the rival claimants to bring legal action. It may then interplead the other party, or upon failure to obtain interpleader. it can serve notice upon the other party of the pendency of the action, coupled with an invitation to defend in that action. The judgment would then liecome res judicata on both parties, and the bank would he relieved of its responsibility. 126

Protection for the Bank - Statulory Requircment of Legal Process. Under the English rule, the bank is protected from the threat of duuble lialility upon the assertion of an adverse claim by the requirement that the bank recognize the nominal depositor as the sole party with the right to the disputed deposit, until and unless restrained by legal process. ${ }^{\mathbf{1 2 \pi}}$ In civil law, whenever an adverse claim is set up, the depositary is not buund tu deliver the funds to either party until title is established, or at all events nut until one party after notice refuses to initiate legal process to determine the title to the property. ${ }^{128}$ But it was not until statutury provisiuns were adopted in a number of the states that some banks in this cumtry were given similar protection.

At the present time, at least eighteen states have some form of adverse claim statute. The usual adverse claim statute, which has with slight variations been adopted in at least thirteen states, ${ }^{120}$ provides that notice of an

124. Walsh v. Bowery Savings Bank, 15 Daly 403, 7 N. Y. Supp. 669 (C. P. 1989) (savings account).

125. See p. 996 supra.

126. See Potter v. Whitten, 170 Mo. App. 10S, 155 S. W. 80 (1913).

127. Paget, Law of Baxkiag (4th ed. 1930) 188.

128. Storx, Ballments (9th ed. 1878) 120, n. 2.

129. ARk. Dig. Stat. (Pope, 1937) \$758: C.AL Gex. Laws (Dcering, 1937) Act 652,

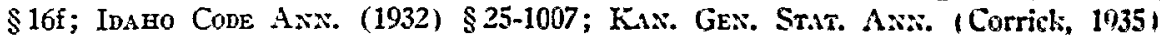
$\$ \$ 9,174$; ME Rer. Stat. (1930) c. 57, \$131; Mr'H. St.1T. Ax:. (Henderson, 1\%36) $\$ 23.311$; N. J. Stat. Axx. (1939) \$17:9-6; N. M. St.st. Axs. (Courtright, 1929) \$13-1015; Onza. Stat. Axa. (Supp. 1941) tit. 6, \$11Sv; Ore. Conrs. L.uWs Awn. (1940) $\$ 40-1005$; P.. Stat. Axx. (Purdon, 1939) tit. 7, \$\$19-905. The statute of Utah differs from these provisions only in that the indemnity bond which may be provided must be for double the amount claimed. This provision scems to protcet fully the bank against possible slander of credit actions. [тан Rev. Stat. Aws. (1933) \$7-3-52. A Montana statute provides that the depositary must give notice to the nominal depasitor of any proceedings taken adversely to his interest, which may tend to excuse the depositary from delivering the deposit to him. Mont. Rev. Cones Axs. (Anderson \& Mlcliarland, 
adverse claim is not effective unless the claimant procures a restraining order, injunction, or other appropriate order from a court of competent jurisdiction in a cause wherein the depositor is a party served with notice of the action; or unless the adverse claimant executes a bond indemnifying the bank for all liability or loss resulting from payment of the claim or dishonor of depositor's checks. The provision is held inapplicable where the depositor is a fiduciary of the adverse claimant, ${ }^{130}$ and when the pertinent facts give reasonable catuse to believe that the fiduciary is about to misappropriate the money. 1 iar The success of these statutes in providing proper protection for banks and litigants is partially attested to by the infrequent litigation which has arisen thereunder.

Action by the Adverse Clainant or the Depositor to Obtain the Disputcd Funds. If after notice of the adverse claim reaches the bank, the bank refuses to pay the balance either to the adverse claimant or the nominal depositor, or refuses to honor the customer's check, the legal action which either of the rival claimants may pursue offers no difficulty. The adverse claimant, even in states wherein no adverse claim statute exists, may proceed by way of attachment, or of injunction to prevent the bank from reducing the amount on deposit. The adverse claimant can also obtain a writ of garnishment directed solely against the amount which he claims to be his. Although such a writ may be anomalous inasmuch as it is directed against a contractual obligation of the bank to the customer at the same time that the plaintiff in the garnishment proceedings alleges that the bank's obligation is to himself and not the nominal depositor, it serves the purpose of securing the fund. Moreover, in the garnishment proceedings a judicial determination of the equitable owner of the fund will serve to settle the problem, at least as far as the adverse claimant is concerned. Finally, the adverse claimant may bring action for a decree declaring him to be the true owner of the deposit, and restraining the bank from paying the nominal depositor. ${ }^{132}$

1935) \$7645. A West Virginia statute omits the mandate that the bank obey legal process as "unnecessary" [W. VA. CODE ANN. (Michic \& Sublett, 1937) \$3210, Reviscrs Note (1929) §3210] and provides merely that a bank should not dishonor the customer's checks unless the adverse claimant executes a bond to cover possible loss from such dishonor. Id.

130. No exceptions are made for fiduciary accounts in New York [N. Y. BANkina Law, §134(5)], Mississippi [Mrss. Code Anv. (Supp. 1938) §644], and South Dakota [S. D. CODE (1939) §6.0416].

131. The California statute carefully provides that, if an affidavit indicates that the fiduciary is about to misappropriate the money, the bank may refusc payment to anyonc, without risking any liability whatsoever on its part. CAL. GEN. LAws (Dcering, 1937) Act $652, \S 16 f$.

132. Spaulding Mfg. Co. v. Chaudoin, 87 Ark. 418, 112 S. W. 1087 (1908); sec Detroit Savings Bank v. Haines, 128 Mich. 38, 87 N. W. 66 (1901) ; 4 PomekoY, EQurrY Jurisdicrion (5th ed. 1941) \$1339; cf. Fontaine-Besson v. Parr's Banking Co., $12 \pi$. L. R. 121 (C. A. 1895). 
The adverse claimant, either before the disputed deposit is acted upon by the bank, ${ }^{133}$ or after the bank has paid the fund to the nominal depositor in open disregard of a notice of the adverse claim, ${ }^{134}$ can maintain an action for money had and received against the bank, and upon proof of his equitable claim, can secure the claimed fund. This action is a common law action for a money judgment, and the claimant cannot be compelled to bring in the nominal depositor. ${ }^{135}$ Of course, the adverse claimant may seek reflress directly from the nominal depositor without disturbing the depusitary. liut such action cannot be classified as an adverse claim problem, for the very essence of an adverse clain involves a claim to the specific sum un depusit with a bank. In some states the adverse claimant also has at his disposal specific statutory procedure which enables him to defend his claim. Fur example, an adverse claim may be determined by a direct action between the rival claimants $;^{136}$ or when attachment is directed against funds in the name of a fiduciary nominal depositor the adverse claimant may intervene to protect his title. ${ }^{13 \pi}$

The depositor, seeking to obtain from the bank the balance of the account or damages for wrongful dishonor of a check, has at his access the same remedies which are available to him when no adverse claim has been arvanced. Even after the bank has made a payment to the alverse claimant, the latter does not lose his right to these forms of action. ${ }^{135}$ Moreover, lie may also in some jurisdictions obtain an injunction to prevent the depusitary from recognizing the denands of the adverse claimant, or if the adverse claimant has received the funds, he may direct his action against him. In addition, the depositor may have additional statutury protection under the varying adverse claim statutes. ${ }^{139}$

\section{Conclusion}

Although adverse claim situations involve the rights of three or more conflicting interests - bank, nominal depositor, adverse claimant, and credi-

133. Johnson-Brinkman Comm. Co. v. Central Bank of Kansas City, 116 M10. 558, 22 S. W. 813 (1893) ; Bruff r. Rochester Trust \& Safe Deposit Co., 118 Mlise. 394,193 N. Y. Supp. 321 (Sup. Ct. 1922); see Shotwell v. Sioux Falls Savings Bank, 34 \$. U. 109, 147 N. IV. $28 S$ (1914); L. R. A. 1915A 715.

134. Whitecotton v. Uilson, 197 S. W. 168 (M1o. App. 1917); cf. Brown v. Uaugherty, 120 Fed. 526 (C. C. D. Mfo. 1903).

135. Walsh v. Nat. Broadway Bank, 11 Misc. 249, 32 N. Y. Supp. 734 (C. P. 1895), aff'd, 13 Misc. 3, 33 N. Y. Supp. 998 (C. P. 1895).

136. See Utah Rev. Stat. Ann. (1933) \$104-54-14.

137. See Ala. Code Axw. (Michic, 1940) tit. 7, $\$ 1168$.

138. Townsend v. Webster Five-Cent Savings Bank, 143 Mass. 147, 9 X. E. 521 (1887) ; see Shotwell v. Sioux Falls Savings Bank, 34 S. D. 109, 147 N. W. $28 S$ (1914), L. R. A. 1915A 715.

139. Under an Idaho Statute, ID.но CODE Axx. (1932) \$12-607, a direct action may be brought against the adverse claimant to determine the obligation of the depositary. 
tors claiming through any one of the three - the problems posed by any of the four different classes of adverse claim cases are in the last analysis uncomplicated and apparent. Only where the rights of the disputing parties become interwoven and the crux of the legal question is the determination of which interests should be rendered paramount, does any real difficulty arise. Because the bank, constantly involved in transactions which present potential adverse claim situations, must be protected against the risk of serious financial loss, the primary emphasis should be on establishing a course of behavior which the bank may follow without being placed at its peril. At the same time the adverse claimant's right of recourse to the specific stm on deposit with the bank, and the credit standing of the nominal depositor must be safeguarded.

These goals will be achieved only if mere notice to the bank of an adverse claim to a bank deposit is held to have no operative effect upon the duties of the bank, a noteworthy provision of adverse claim statutes. Only after the adverse claimant has affirmatively acted by securing legal process to enjoin further disposition of the funds prior to a judicial determination, in which litigation the depositor should be made a party contestant through proper service, should the bank be held responsible to the adverse claimant. ${ }^{140}$ If the legal concept of notice be retained, a less ambiguous definition of notice must be formed. Moreover, the claimant should be forced to take legal action within a definite period of time after notice reaches the bank, and failure to do so should automatically render the notice inoperative; such legal action should also be directed against the nominal depositor who should be included as a party defendant. For protection of the rival claimants, the bank should then be obligated to dishonor all of the depositor's checks presented stibsequent to the receipt of legal process or adequate notice which reduce the customer's balance below the sum claimed, and to refuse any demand by the adverse claimant for the money. Upon a determination through litigation of the equitable ownership, or upon compromise between the rival claimants, the bank should then be freed of all liability by payment to the proper party. If it desires, the bank should be allowed to make a payment of the disputed sum into court and then be dismissed as a non-interested party.

Legislation which would outline such an automatic process for the assertion of an adverse clain would be most desirable for the bank, for danger of double liability through no negligence of its own would be removed. The adverse claimant, certain that the claimed deposit would be available upon a judgment in his favor, need not be given any further protection. The nominal depositor, of course, would suffer somewhat by the indiscriminate

140. The bank should have the power to interplead the nominal depositor if the claimant fails to have the depositor served. This power may be granted under a liberal interpleader statute. 
dishonoring of his checks, but he would be put in no worse position than he is upon the garnishment of his account, when upon receipt of garnishment process, the bank may not honor the checks of the depositor. In mitigation. if the adverse claim is invalid, the adverse claimant should be liable for the damages that the depositor suffers from the dishonor of his check. Legislative action to achieve these results by adoption of adverse clain statutes has been successful, but is at present linited to some sixteen states. In the absence of such legislation, it remains with the courts to clarify adverse claim transactions by adopting more protective and more certain legal principles. 